Talanta

January 2016, Volume 147, Pages 581-589

http://dx.doi.org/10.1016/i.talanta.2015.10.036

http://archimer.ifremer.fr/doc/00286/39695/

(C) 2015 Elsevier B.V. All rights reserved.

\title{
Rapid detection and quantification of the marine toxic algae, Alexandrium minutum, using a super-paramagnetic immunochromatographic strip test
}

\author{
Gas Fabienne ${ }^{1}$, Baus Béatrice ${ }^{1}$, Quere Julien ${ }^{2}$, Chapelle Annie ${ }^{2}$, Dreanno Catherine ${ }^{3,{ }^{*}}$
}

${ }^{1}$ CEA Marcoule, Direction des Sciences du Vivant, Laboratoire d'Innovations technologiques pour la Détection et le Diagnostic-, Bagnols-sur-Cèze, F-30200, France

2 IFREMER, Centre de Brest, Dyneco Pelagos, Plouzané, F-29280, France

${ }^{3}$ IFREMER, Centre de Brest, Laboratoire Détection, Capteurs et Mesures, Plouzané, F- 29280, France

* Corresponding author: Catherine Dreanno, Fax: +33 298224151 ;

email address : catherine.dreanno@ifremer.fr

\begin{abstract}
:
The dinoflagellates of Alexandrium genus are known to be producers of paralytic shellfish toxins that regularly impact the shellfish aquaculture industry and fisheries. Accurate detection of Alexandrium including Alexandrium minutum is crucial for environmental monitoring and sanitary issues. In this study, we firstly developed a quantitative lateral flow immunoassay (LFIA) using super-paramagnetic nanobeads for $A$. minutum whole cells. This dipstick assay relies on two distinct monoclonal antibodies used in a sandwich format and directed against surface antigens of this organism. No sample preparation is required. Either frozen or live cells can be detected and quantified. The specificity and sensitivity are assessed by using phytoplankton culture and field samples spiked with a known amount of cultured $A$. minutum cells. This LFIA is shown to be highly specific for $A$. minutum and able to detect reproducibly $10^{5}$ cells $/ \mathrm{L}$ within $30 \mathrm{~min}$. The test is applied to environmental samples already characterized by light microscopy counting. No significant difference is observed between the cell densities obtained by these two methods. This handy super-paramagnetic lateral flow immnunoassay biosensor can greatly assist water quality monitoring programs as well as ecological research.
\end{abstract}




\section{Graphical abstract :}

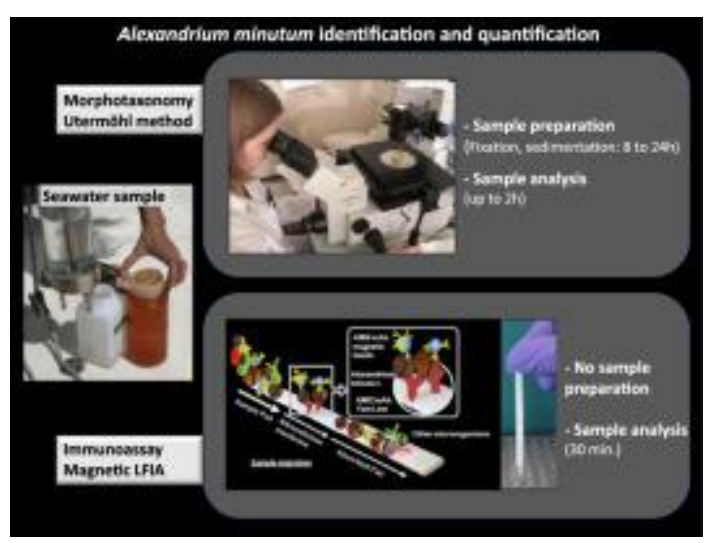

\section{Highlights}

A fast and highly specific magnetic LFIA to detect and quantify a toxic microalgae. The magnetic LFIA is able to quantify living and frozen whole cells. The efficiency of LFIA was compared to standard method during bloom monitoring. This user-friendly biosensor can be used for rapid on site testing. This quantitative LFIA will improve the performance of the monitoring program.

Keywords : Alexandrium minutum, Detection, Quantification, Dipstick lateral flow immunoassay, Superparamagnetic 


\section{Introduction}

The Harmful Algal Blooms (HABs), also known as "red tide" are common and natural phenomena. Nevertheless, their occurrence and geographical extent have been increasing constantly over recent years [1]. A combination of several factors, such as global warming [2], eutrophication of the coastal zones [3] or increase in maritime transport which leads to the introduction of new invasive species [4] is thought to be responsible for HABs. The coastal ecosystem and consequently the fisheries economy, the aquaculture industry and tourism are all affected. Detection of HABs has become a challenging concern due to the direct impact on public health and economy. Phytoplankton and biotoxin monitoring is essential to ensure public safety and to protect the aquaculture industry through early detection systems for these toxic events.

One of the most critical and widespread HAB poisoning syndromes is Paralytic Shellfish Poisoning (PSP), which is due to the consumption of contaminated shellfish. Dinoflagellates belonging to the genus Alexandrium, are among the main toxic microalgae responsible for PSP outbreaks in most temperate waters throughout the world [5]. Of the more than 30 morphologically defined species in this genus, at least half is known to be toxic or to have otherwise harmful effects [6]. In Europe, Alexandrium minutum [7] is one of the main species responsible for the toxic blooms. These microalgae produce potent neurotoxins such as saxitoxins, spirolides and goniodomins. The biosynthetic pathway and genes responsible for saxitoxin synthesis have recently been reported and characterized in Alexandrium [8, 9]. All the toxic species possess the A4 domain of sxtA, which is essential to saxitoxin-synthesis [8]. An accurate and early identification of toxic microalgae is absolutely needed for determining the onset of a toxic bloom and for taking appropriate and efficient preventives measures in shellfish aquaculture and harvesting. Standard discrimination within the Alexandrium genus is based on the examination of morphological characteristics [10] and the exact determination is tedious and requires considerable taxonomic experience since these species-specific features can be very similar among species. Furthermore, the taxonomic patterns can even vary in relation to environmental conditions and intermediate forms have been observed [6]. Microscopic methods, which are used as the standard procedure for HAB monitoring [11] can be time consuming and insufficient to determine phytoplankton at species level in assessing toxic threats in coastal waters. To solve these problems and improve the monitoring efficiency, several alternative molecular methods for the detection of toxic microalgae species have been developed $[1,11]$. 
Various of these technics are capable of identifying $A$. minutum cells, including immunological assays $[12,13,14]$ and genetic methods generally based on DNA probe hybridization (i.e fluorescence in situ hybridization (FISH) on fixed cells [15, 16]; on Q-PCR techniques [17, 18], isothermal amplification [19], on microarrays [20-24] Biosensor detection system have also been recently developed [25-28]. These molecular and immunological based methods tend to require expensive devices or complicated protocols and are limited to laboratory based settings.

For routine monitoring purposes, a method needs to be user-friendly, rapid, accurate, cost effective and be tested into the field or in remote locations. Lateral flow immunoassay (LFIA) widely meets these criteria and specifications. Since 1990; its use has grown tremendously in the diagnostic industry [29]. LFIA has been widely developed and used for the detection of pathogens, drugs and other analytes in resource-poor or non laboratory environments.

Regarding the marine phytotoxins detection, the available LFIAs are based on the use of colloidal gold nanoparticles [30-36], because of its physical stability and low cost. However, the use of this signal reporter can only enable a semi-quantitative analysis based on visual observation without precise data [37]. These tests indicate whether a toxin concentration is below the limit of detection (LOD). They are optimized for shellfish safety assessment and can unfortunately not be used to monitor water quality because of their lack of sensitivity. Recently, an immunostrip detecting was developed allowing the detection of whole cells of $A$. minutum in sea water [38]. In this system, a pair of monoclonal antibodies is used to construct a sandwich immunoassay, in which colloidal gold particles were coupled to one of the antibodies to capture the target microalgae, while the another antibody was immobilized on the detection zone. Even although this test is specific, it remains semi-quantitative and lacks sensitivity. The detection limit is estimated to be about $5.10^{7}$ cells/L.

To overcome these issues, many new labels (see review 39) such as magnetic particles [3948], fluorescent conjugates [49-52] quantum dots [53-56] have been used in LFIA, all of them improving detection sensitivity, quantification and thus accuracy.

Application of super-paramagnetic nanobeads as labels for rapid tests for detection and quantification of microalgae seems to be especially judicious. The natural matrix (i.e seawater) contains a lot of diverse microorganisms (bacteria, phytoplankton, zooplankton, etc) and organic suspended matter that often interfere with the LFIA detection system. It is mainly due to the natural fluorescence, colors and turbidity of these samples. The magnetic beads are a robust label as there is usually an extremely low magnetic noise background in biological samples [29, 39, 40, 41, 57]. In contrast to the other types of nanoparticles, all magnetic signals originating from the magnetic nanoparticles within the entire volume of the membrane, including those present beneath the surface and which cannot be seen optically, can be detected by magnetic reader. The other methods all depend on optical detection, 
which unfortunately is limited to signal coming from the top $10 \mu \mathrm{m}$ of the nitrocellulose [29, 39]. The sensitivity of magnetic FLIA is thus much higher. Unlike other kinds of labels, magnetic signal does not degrade over time improving the sensitivity [39] and coming in handy for sample banking as well. Surprisingly, despite all the advantages of this technology and this label, few commercial magnetic reader devices have been developed [29].

The aim of the current study is to provide a simple and convenient test for the detection and quantification of $A$. minutum cells, which can be used under field conditions. The system we developed involves a sandwich format LFIA labeled with super-paramagnetic nanoparticles and a portable assay reader (Magnisense). The specificity and sensitivity of the method were assessed with Sea water samples spiked with dinoflagellate and $A$. minutum cultures. The LFIA was subsequently used to monitor the temporal distribution of $A$. minutum in the bay of Daoulas and Penze estuary (Brittany, France) during several blooming seasons. The results were compared to those obtained by the traditional standard optical microscopy procedure.

\section{Materials and methods}

\subsection{Chemicals reagents, ICA components and apparatus}

All buffers and chemicals were analytical grade and purchased from Sigma-Aldrich. The super-paramagnetic particles (Estapor) are provided by Merck Millipore (Germany). The nitrocellulose membrane (CNPC-SS12-L2-H50), glass fiber sample pad (GFB-R7L), absorbent pad (AP-080) and the conjugate release matrix polyester (PT-R5) were supplied by Advanced Microdevices LdT (Ambala Cantt, India). The dispensing system (Biojet XYZ 3000)) and guillotine (CM 4000) cutter were purchased from BioDot Inc (Irvine, CA, USA). The magnetic assay reader (Miatek ${ }^{\circledR}$ ) was developed by Magnisense (France). The alkaline lugol's iodine solution (10 $\mathrm{g}$ potassium iodide $(\mathrm{KI}), 5 \mathrm{~g}$ iodine $\left(\mathrm{I}_{2}\right), 25 \mathrm{~g}$ sodium acetate, 100 $\mathrm{mL}$ distilled water) was filtered through a fluted filter and stored in the dark.

\subsection{Monoclonal antibodies}

Two monoclonal antibodies (AMI2 and AMI6) against Alexandrium minutum were selected for their high specificity. The induction, production, and characteristics have been previously reported [13]. These IgG monoclonal antibodies were purified on a protein G HiTrap1 affinity column (GE Health care Life sciences) and stored in PBS.

\subsection{Phytoplankton samples}

All microalgae cultures came from Ifremer's microalgae collection. The phytoplankton strains were cultivated in $f / 2$ Guillard and Ryther medium under optimal temperature $\left(16-18^{\circ} \mathrm{C}\right)$ with $150 \mu \mathrm{E} / \mathrm{m} 2 / \mathrm{s}$ from a cool-white fluorescent light with a 14:10 LD photoperiod [58]. At the end of the exponential growth phase, cells are harvested by centrifugation (5000 g, $10 \mathrm{~min}$ ) and 
kept frozen at $-70^{\circ} \mathrm{C}$ for later use; to check if dead frozen cells can be used without bias, a preliminary experiment investigating the LFIA performance compared frozen cells with fresh motile cells was carried out.

Each sample used for the immunochromatographic assay is prepared from these frozen cell stock solutions, by dilution in natural filtered seawater, that was collected at Saint Anne du Porzic $\left(48^{\circ} 21^{\prime} \mathrm{N}\right.$; $4^{\circ} 33^{\prime} \mathrm{W}$; Brittany, France). Seawater was filtered through Millipore paper with a pore size of $0.45 \mu \mathrm{m}$.

\subsection{Conjugation of super-paramagnetic particles with monoclonal antibodies}

The monoclonal antibody AMI2 was determined as optimal for the capture while the AMI6 $\mathrm{mAb}$ was optimal for the detection. The carboxyl-functionalized super-paramagnetic nanobeads (Estapor M1/02050, average size: $200 \mathrm{~nm}$ ) are conjugated with the mAb AMI6 using the EDC/NHS activation coupling method. In short, beads are firstly diluted at $1 \%$ in activation buffer (10 $\mathrm{mM} \mathrm{NaH}_{2} \mathrm{PO}_{4} \mathrm{pH} \mathrm{6,)} \mathrm{and} \mathrm{washed} \mathrm{twice} \mathrm{in} \mathrm{this} \mathrm{activation} \mathrm{buffer} \mathrm{using} \mathrm{a}$ DynaMag $^{\mathrm{TM}}-2$ magnet (Life technologies, Thermo Fisher scientific) for magnetic separation. Subsequently, the particles are mixed with $52 \mathrm{mM}$ EDC and $27 \mathrm{mM}$ sulfo-NHS in activation buffer for one hour at room temperature. Then, the beads are washed twice with coupling buffer (100 mM borate buffer, $\mathrm{pH}$ 8.6) and re-suspended in $1 \mathrm{~mL}$ of the same buffer. Then, the AMI6 monoclonal antibody is added and adjusted to obtain a final $100 \mathrm{mg} / \mathrm{g}$ surface saturation (100 mg of protein/ $\mathrm{g}$ of nanobeads). This suspension is incubated overnight at room temperature under constant mixing. This step allows the formation of astable amide bond between the antibody and the super-paramagnetic particles. Finally, $30 \mu \mathrm{L}$ of $1 \mathrm{M}$ ethanolamine is added for 30 minutes to stop the reaction. After magnetic separation, the supernatant is discarded and the beads are mixed for 4 hours at ambient temperature with a blocking solution containing $50 \mathrm{mM}$ Tris, $0.2 \%$ Tween 20 and $1 \% \mathrm{BSA}$ at $\mathrm{pH} 7.5$ to block any residual active coupling sites. After washing, the conjugated magnetic particles are resuspended and stored at $4{ }^{\circ} \mathrm{C}$ in blocking solution added of $0.1 \%$ sodium azide. Prior to use, a sample of the conjugated nanobeads is inspected under the microscope to verify the mono dispersity. In case of particle aggregation, the solution is sonicated for $1 \mathrm{~min}$ on ice using a sonifier 450 sonicator (Branson, Germany).

\subsection{Preparation of the immunochromatography strips}

The immunostrip is composed of three parts (sample pad, nitrocellulose membrane and absorbent pad) as shown in figure 1. The pads are placed onto the nitrocellulose membrane, which in turn is pasted to an adhesive plastic. The capture antibody (anti-Alexandrium minutum AMI2) is diluted in PBS at a final concentration of 1.5 to $7.5 \mathrm{mg} / \mathrm{mL}$, and then added directly onto the nitrocellulose using a lateral flow dispenser (Biojet XYZ 3000) to form the 
test line $(1 \mu \mathrm{L} / \mathrm{cm})$ (see Figure 1). The sample pad is positioned on top of the nitrocellulose with an overlap of $2 \mathrm{~mm}$ while the absorbent pad is set up similarly on the other end of the membrane. The whole assembled plate is cut lengthwise and divided with a guillotine cutter (CM 4000) in $4.3 \times 75 \mathrm{~mm}$ strips. They are placed in a $37^{\circ} \mathrm{C}$ air incubator for $1 \mathrm{~h}$ to dry, and then kept at room temperature in dessicating incubator (super Dry Totech) for long term storage.

\subsection{Dipstick assay}

In a 96 -wells round bottom microplate or in a hemolyse tube, $50 \mu \mathrm{L}$ of conjugate mAb AMI6magnetic beads are mixed with $50 \mu \mathrm{l}$ of a microalgae sample. The immunostrip is then added to each well or tube, causing the sample to wick up into the dipsticks. After a 15-60 min incubation, the strip is removed from the well, and placed into a specific plastic board to facilitate the detection of the magnetic signal by the magnetic assay reader (Miatek ${ }^{\circledR}$, Magnisense). The principle of the method is based on the non-linear behaviour of magnetic beads in an alternating magnetic field [59, 60-62]. In contrast to conventional methods which measure the magnetic susceptibility, the device measures only the non-linear impact of the superparamagnetic particles on the excitation magnetic field. Briefly, the magnetic beads are exposed to a magnetic field at two frequencies $\mathrm{f} 1$ and $\mathrm{f} 2$. The non-linearity of supermagnetic materials causes an intermodulation between both frequencies and generates new spectral components in the spectrum of the measured voltage. The amplitude of these novel peaks is proportional to the volume of the magnetic bead. The response is then measured by combining the frequencies e.g. at $f=f 1 \pm 2 \times f 2[59,60]$. The detected signal given by the device is therefore directly proportional to the amount of super-paramagnetic particles captured onto the test line.

\subsection{Optimisation of the reaction conditions for $A$. minutum detection}

The super-paramagnetic LFIA is optimized by varying the composition of the buffer, the blocking compounds and their concentration, the type of super-paramagnetic particles and the reaction time. The optimal conditions were determined to be those that provided the best assay reproducibility and the lowest detection limit of $A$ minimum.

\subsection{LFIA performance}

The specificity of the LFIA is investigated using several dinoflagellate species, Alexandrium minutum, Alexandrium catenella, Alexandrium tamarense, Heterocapsa triquetra, Prorocentrum lima, Prorocentrum micans and Scripsiella trochoida. Each species sample is diluted to $10^{7}$ cells. $L^{-1}$ with natural seawater. Fifty microliters of sample were used to perform the super-paramagnetic LFIA. 
The performance of LFIA on frozen and fixed samples in different concentrations of Lugol's iodine solution was also investigated. This fixative solution is the most commonly used in phytoplankton monitoring programs [11]. Lugol's iodine solution was directly added to samples, which were then stored in the dark at $4^{\circ} \mathrm{C}$ before analysis.

To get insight in the LFIA sensitivity, cultures of $A$. minutum were used to spike natural seawater samples at various concentrations from $10^{2}$ to $10^{8}$ cells. $L^{-1}$. The seawater was observed under microscope to control the absence of $A$. minutum before using it.

To validate the assay, environmental samples were collected in the bay of Daoulas $\left(48^{\circ} 20^{\prime} \mathrm{N}\right.$, $4^{\circ} 17^{\prime} \mathrm{W}$; Brittany, France) from June to August 2013 and 2014. The highest abundances of $A$. minutum occurred during these periods. Water samples were taken from the sea surface using an $8 \mathrm{~L}$ Niskin bottle; $100 \mathrm{~mL}$ of sea water was used for microscopic cell counts and preserved by adding neutral Lugol's iodine solution. Fixed phytoplankton samples were counted according the method of Utermöhl using a hemocytometer [11]. Additionally $500 \mathrm{~mL}$ seawater was collected for the LFIA experiments. In order to concentrate the sample, 100 $\mathrm{mL}$ of seawater was vacuum filtered through an Isopore membrane (Millipore, Germany) with a pore size of $1.2 \mu \mathrm{m}$. The algae were recovered and re-suspended in $1 \mathrm{~mL}$ of filtered seawater. Samples were then frozen and stored at $-80^{\circ} \mathrm{C}$ until LFIA analysis.

\subsection{Statistical analysis}

At least three replicates were performed for each experiment. Results are indicated as the mean \pm SEM. Data were assessed for normality and homogeneity of variance before performing the rest of analysis. The natural logarithm was used to transform the data to meet this assumption. A two tailed Student's t-test was performed to detect any difference in $A$. minutum cell concentrations obtained by morphotaxonomy, i.e the traditional standard optical microscopy procedure and the LFIA method. The effect of Lugol's iodine preservation of sea water samples was assessed by simple analysis of variance (ANOVA). When differences were significant $(P<0.05)$, a Tukey a posteriori multiple range test was used for comparison. In order to test the influence of the freezing process, a Wilcoxon test was applied. An ANOVA was used to compare the slope of linear regression derived from the morphotaxonomy count data with that of LFIA to the theoretical 1:1 correlation. Statistical analysis was carried out in Minitab version 17 for windows.

\section{Results and discussion}

\subsection{The magnetic immunochromatographic assay}

Figure 1 illustrates the principle behind this dipstick lateral flow immunoassay based on super-paramagnetic nanobeads. Samples are first mixed with the mAb AMI6 - conjugated 
super-paramagnetic beads in a microplate well. If $A$. minutum cells are in a sample, these cells will be first captured by the magnetic antibody conjugate. Then, as the sample moves from the sample pad into the nitrocellulose strip, some of the cell-particles complexes will be trapped by another $A$. minutum - specific mAb, AMI2 adsorbed onto the test line. The two monoclonal antibodies (AMI2 and AMI6) recognize different epitopes of the same microalgae, i.e $A$. minutum. The biochemical nature of the recognized antigens is as yet unknown. In the presence of $A$. minutum cells, a sandwich will be formed at the test line between mAb-AMI2 and the complex formed between the algal cells and the-mAb-AMI6magnetic beads conjugate. This complex displays a brown color on the test line in the presence of algal cells which appears quickly after about $10 \mathrm{~min}$. No bound residual conjugates will migrate into the adsorbent pad. Our results are in agreement with those previously shown by Gas et al. [38]. These authors developed a LFIA format implementing smaller gold colloids $(40 \mathrm{~nm})$ using a different monoclonal capture antibody (AMI11) for the detection of whole A. minutum cells. Surprisingly, the whole algae cells, whether living (and thus motile) or dead are able to diffuse without restriction through the porous nitrocellulose membrane. The migration of microalgae along the strip can be assessed by fluorescence microscopy using 460-500 nm excitation revealing the red chlorophyll fluorescence of the algae (data not shown). At the beginning of the assay, the algal cells were found on the sample pad and after a few minutes of flow migration in the nitrocellulose membrane. At the end of the assay, a few cells remained in the sample pad and some had reached the absorbent pad. However, most of them were captured on the test line. Even if Alexandrium genus cells are rather large unicellular organisms with cell diameter varying from 10 to $50 \mu \mathrm{m}$ [10] when compared to other microorganisms, such as bacteria, spores and virus [37, 48, see review $63,64-66]$, they can migrate along the strip and be detected by LFIA.

\subsection{Relationship between the visual line and the magnetic signal}

As shown in figure 2, the visual intensity of the Test line increases with algal concentration. When the sample migration is complete, the magnetic signal is measured all along the strip every $2 \mathrm{~mm}$ with the MIAtek ${ }^{\circledR}$ reader coupled to a small automate in order to assess the efficiency of the chromatography. In all conditions a very low signal was recorded on the sample pad (zone A) showing that the super-paramagnetic beads do not stay in the sample pad and flow through the nitrocellulose membrane up to the absorbent pad, where they complete their migration. Several media such as phytoplankton culture medium, PBS buffer and natural seawater containing no algae were also assessed. These controls show a very low magnetic signal of around 200 a.u on the nitrocellulose membrane (zone B.). This might be due to an unspecific adsorption of the conjugate on nitrocellulose membrane, since no magnetic signal is present when no conjugate is mixed into the sample solution. On the 
absorbent pad (zone C) we observe an increasing curve of the magnetic signal, corresponding to the beads which were not retained on the test line (Figure 2). The intensity of this signal is inversely proportional to the cell concentration. A Control line ( $C$ line) consisting of anti-species IgG is usually included in LFIA strip. The excess of mAb conjugated magnetic particles and residual complexes can bind to this control line. We do not set up a $C$ line since the MIAtek ${ }^{\circledR}$ reader is not designed to read simultaneously the magnetic signals at two positions of the strip, i.e Test and Control lines. In contrast to conventional methods which measure the magnetic susceptibility, Miatek ${ }^{\circledR}$ reader measures only the non linear response of magnetic particles on the excitation magnetic field, allowing reliable and easy discrimination of these particles from paramagnetic materials [59-62]. When filtered natural sea water or other matrix without added super-paramagnetic beads was assessed, no specific magnetic signal could be ever measured (data not shown). If a magnetic signal is recorded, it is without any doubt the signature of a magnetic bead presence. Consequently it is unnecessary to use a control line; these tests gave complete confidence in our method and the data obtained.

When $A$. minutum cells are spiked into the sample, the magnetic signal reaches a peak at the Test Line, where a visual brown line appears. The magnetic signal measured at the Test line is proportional to the algal concentration. The MIAtek ${ }^{\circledR}$ reader window is then adjusted to $40 \mathrm{~mm}$, which corresponds to the test line on the strip, to be able to register the maximum magnetic value for the data set.

\section{3- Optimization of the magnetic immunoassay}

To improve detection sensibility of $A$. minutum cells, the experimental conditions including the type of super-paramagnetic beads, the conjugate buffer, the strip assembly, the antibody concentration spotted on the membrane and the sample and conjugate volumes were optimized systematically. The best results in terms of sensitivity and reduced background were obtained with $50 \mathrm{mM}$ Tris-HCl buffer containing $0.2 \%$ Tween, $1 \% \mathrm{BSA}$ and $5 \%$ Sucrose as conjugate buffer. The best assembly is obtained when the fiber glass and the absorbent pad were covering the nitrocellulose membrane for $2 \mathrm{~mm}$.

From the concept of the method, the concentration of the capture antibody must be one of the major keys for the success of LFIA development. However, most magnetic immunostrips usually just add $1 \mu \mathrm{g} / \mathrm{cm}$ of capture antibody without any experimental optimization of antibody concentrations [43]. In our hands, the concentration of the AMI2 mAb capture antibody was clearly very important.

The AMI2 mAb capture antibody was spotted at several distinct concentrations $(1 ; 1.5 ; 2.5 ; 5$; $7.5 \mu \mathrm{g} / \mathrm{cm}$ ) and the LFIA was performed using $10^{7}$ cells. $\mathrm{L}^{-1}$ per sample. The magnetic signal increased with the antibody concentration and reached a plateau at $2.5 \mu \mathrm{g} / \mathrm{cm}$ Ab-AMI2 
amount (data not shown). Therefore, we chose to load the AMI2 mAb systematically with 2.5 $\mu \mathrm{g} / \mathrm{cm}$ to gain highest assay sensitivity.

\subsection{Specificity of the magnetic immunoassay}

To assess the specificity of the magnetic LFIA for detection of $A$. minutum cells, several species of dinoflagellates including the closely related $A$. catenella and $A$. tamarense were tested at high concentrations. As shown in figure 3, no significant cross-reactivity could be detected. All of the negative control microalgae yielded test line values similar to those of filtered seawater. We confirm therefore the strong specificity of the monoclonal antibodies developed by Gas et al. [13]. This FLIA can easily distinguish A. minutum from its closest relatives and makes it suitable for specific identification of this species in seawater samples. We then examine if it is possible to analyse fixed or frozen phytoplankton by LFIA. All magnetic signals obtained from fixed or frozen cell samples were compared to those from fresh cells samples. There is no significant effect of the freezing process on LFIA performances (Table 1). The mAb AMI6 and AMI2 are able to recognize frozen A. minutum in PBS or seawater, confirming previous studies carried out by Gas et al. [13]. Lugol's iodine solution contains oxidizing agents, and is the most commonly used fixative for preserving phytoplankton samples. It is relatively safe and thought to be better for accurately quantifying cells than many of the aldehyde-based fixatives $[11,67]$. When Lugol's iodine fixative is added at a concentration higher than $0.5 \%$, the magnetic signal of fixed samples is significantly reduced (Table 2). Microscope observations of preserved sample do not show any cell breakage neither clumping. It seems that the mAb can no longer bind to the $A$. minutum antigen on cell surface. Naik et al. (2010) [68] observe that Lugol's can dissolve hard structures of cell phytoplankton. Nevertheless, this fixative can be used safely at a $0.5 \%$ concentration up to 1 week at $4^{\circ} \mathrm{C}$. If seawater samples cannot be analyzed quickly, freezing appears to be the safest and most effective way for long term preservation for LFIA analysis.

\subsection{Quantitative magnetic immunoassay}

As shown in figure. 4, the magnetic signal obtained from the LFIA is proportional to the sample concentration of $A$. minutum in a range from $10^{5}$ to $10^{8}$ cells/L. The resulting calibration plot of the magnetic measurements versus the log transformation of cells concentration is a linear model $\left(R^{2}: 0.98, y=44.515 \ln ([x])-234.5\right)$, thus enabling easily the determination of $A$. minutum concentration from an unknown sample. Nevertheless we observed that the magnetic signal intensity can vary depending on the conjugate lot (data not shown). Therefore a calibration curve needs systematically to be established for each experiment to get an accurate quantification. The lower limit of detection (LOD) defined as the mean value of filtered natural seawater (without $A$. minutum cells) plus three times the 
standard deviation occurs at 4.38. $10^{4}$ cells/L, while the lower limit of quantification (LOQ) determined as the lowest point on the relatively straight portion of the curve is around $10^{5}$ cells/L. The $L O Q$ is higher than the LOD, indicating that the $L O Q$ is the true limit of the assay. The sensitivity of our magnetic LFIA is 100 times lower than the one obtained with the gold immunochromatic assay using similar monoclonal antibodies [38], demonstrating the great advantage of using magnetic particles as detection system to measure low quantities of "products" in samples.

To further test the LFIA efficiency on an environmental matrix, seawater samples containing natural phytoplankton assemblages were spiked with $A$. minutum cells in several concentrations. A prior inspection under the light microscope did not reveal any presence of Alexandrium sp. in seawater before spiking. A. minutum cells were successfully detected and quantified afterwards (Table 3 ). The results are compared to optical counting and showed that cell concentrations determined by both methods were significantly the same $(P>0.05)$, Nevertheless, when samples show cell concentration near the LOQ, the ratio (OM/LFIA) falls to 0.5 showing that this assay has to be used for cell concentration higher than $5.10^{4}$ cells/L (Table 3 ). In France, recurrent blooms of $A$. minutum mainly occur in the northwest estuaries during the June-July period [69, 70]. They often reach cell concentrations $>1.10^{5}$ cells $L^{-1}$. Under these circumstances, for sanitary monitoring purposes, when the alert threshold of 10000 cell $\mathrm{L}^{-1}$ is exceeded, biotoxin analysis is performed in shellfish. Under our experimental conditions, determining a concentration of $10^{4}$ cells. $L^{-1}$ would be tantamount to detect one single cell by our developed LFIA. Therefore, in order to meet this sanitary alert threshold, an easy-to-perform phytoplankton concentration step prior to the assay has to be carried out to overcome this relatively lack of sensitivity of our LFIA.

A total of 50 phytoplankton samples collected in the Bay of Daoulas and Penze estuary during three blooming seasons (2012-2014) are analysed by LFIA and optical microscopy methods in order to evaluate the performances of the new method (Figure 5). Seawater samples were pre-concentrated one hundred times by filtration. Taken into account the $\mathrm{LOQ}$, every sample showing an $A$. minutum concentration lower than 1000 cells. $\mathrm{L}^{-1}$ is discarded from the statistical analysis. Nevertheless, no false negative and positive sample was ever recorded taking into account the sanitary threshold at 10000 cells. $L^{-1}$. Even if few differences were noted between the microscopic observations and LFIA for low cell densities (i.e $<10^{4}$ cells. $\mathrm{L}^{-1}$ ), they did not impact management decisions. There is a significant correlation $(\mathrm{P}<0.05)$ between the $A$. minutum cells concentration determined by LFIA and optical microscopy. The comparison of both sets of measure shows a very good correlation $\left(R^{2}=0.78\right)$. The slope of the relationship is 0.93 which indicates that the counts obtained by LFIA tend to be slightly lower than those obtained by microscopy. Nevertheless, the 
observed linear regression is not statistically different from the theoretical correlation line (1:1). The slight underestimation by LFIA might be due to the losses of cells during the preconcentration step of seawater. Discrepancies could be also related to differences in the sampling volumes used for the analysis. The seawater volume sampled for cell counting by light microscopy $(10 \mathrm{~mL})$ is smaller than that analysed for the LFIA $(100 \mathrm{~mL})$. Misidentification and counting errors cannot therefore be excluded. Even if the Utermöhl procedure is the most widely used standard method for phytoplankton identification and enumeration ( $f . i$ European Standard EN 15204 [71]), the microalgae identification by microscopic observation remains a subjective procedure. The precision and detection limit of this method depends on the number of algal cells and fields observed and counted. We can also not rule out that potential variations of expression of the biomarker recognized by the monoclonal antibodies occur under field conditions. In the laboratory, we did not observe any significant difference when quantifying $A$. minutum cells that were sampled at various stages of a phytoplankton culture (data not shown). The biochemical characterization of the AMI6 and AMI2 monoclonal antibodies epitope is unknown and is currently under way. Their identification could open new opportunities to create new pertinent biomarkers for microalgae. The initial results obtained with field samples are very encouraging and successfully demonstrated the potential of our magnetic LFIA to quantify $A$. minutum cells for monitoring or research purposes.

\section{Conclusion}

Here, an immuno-chromatographic assay format using super-paramagnetic nanobeads to detect and quantify the toxic algae, A. minutum, in sea water has been successfully developed. To our knowledge, this is the first time that whole microalgae cells can be quantified using a magnetic LFIA test. This assay provides a quantitative signal which can be used to accurately estimate $A$. minutum concentrations in seawater samples. The assay is direct, rapid (30 min), specific, robust, convenient and easy to use. It does not involve any sample preparation or amplification step, it is thus less error prone. We strongly believe that this test should prove advantageous for shellfish farmer and many other applications where proliferation of toxic algae needs to be monitored. Moreover, this versatile technique can be easily used under field condition.

\section{Acknowledgements}

This work was financially supported by the Carnot institutes (Ifremer Edrome) and by the Conseil régional de Bretagne (France). We thank Dr. C. Compere (Ifremer) and Dr. V. Tanchou (CEA) for fruitful discussions. We are deeply grateful to Dr. S. Béseme, L. Lenglet, L. Santoro, (Magnisense, www.magnisense.com) for their constructive advice and support 
throughout this research project. We would like to thank Dr. Marcel Koken (CNRS) for critically reading the manuscript and correcting errors in English.

\section{References}

[1] D.M. Anderson, A.D. Cembella, G.M. Hallegraeff, Progress in understanding harmful algal blooms:paradigm shifts and new technologies for research, monitoring and management, Annu. Rev. Marine. Sci. 4 (2012) 143-176.

[2] B. Dale, M. Edwards, P.C .Reid, Climate change and harmful algal blooms, In: E. Graneli, J.T. Turner (Eds.), Ecology of harmful algae, Springer, (2006), 367-378.

[3] J. Heisler, P.M. Glibert, J.M. Burkholder, D.M. Anderson, W. Cochlan, W.C. Dennison, Q. Dortch, C.J. Gobler, C.A. Heil, E. Humphries, A. Lewitus, R. Magnien, H.G. Marshall, K. Sellner, D.A. Stockwell, D.K. Stoecker, M. Suddleson, Eutrophication and harmful algal blooms: A scientific consensus, Harmful algae, 8 (2008) 3-13.

[4] D.M. Anderson, Turning back the harmful red-tide-commentary, Nature, 388 (1997), 513514.

[5] L. Galluzzi, E. Bertozzini, A. Penna, F. Perini, E. Garces, M. Magnani, Analysis of rRNA gene content in the Mediterranean dinoflagellate Alexandrium catenella and Alexandrium taylori: implications for the quantitative real-time PCR-based monitoring methods, J. Appl. Phycol. 22 (2010) 1-9.

[6] D.M. Anderson, T.J. Alpermann, A.D. Cembella, Y. Collos, E. Masseret, M. Montresor, The globally distributed genus Alexandrium: Multifaceted roles in marine ecosystems and impacts on human health, Harmful algae 14 (2012) 10-35.

[7] Y. Halim, Alexandrium minutum nov. g. nov. sp. dinoflagellé provocant des 'eaux rouges', Vie Milieu, 11 (1960), 102-105.

[8] A. Stüken, R.J.S. Orr, R. Kellmann, S.A. Murray, B.A. Neilan, K.S. Jakobsen, Discovery of nuclear-encoded genes for the neurotoxin saxitoxin in dinoflagellates, PLoS One (2011) 6, e20096.

[9] J.D. Hackett, J.H. Wisecaver, M.L. Brosnahan, D.M. Kulis, D.M. Anderson, D. Bhattacharya, F.G. Plumley, D.L. Erdner, Evolution of saxitoxin synthesis in cyanobacteria and dinoflagellates, Mol. Biol. Evol. 30 (2013) 70-78.

[10] E. Balech, the genus Alexandrium Halim (Dinoflagellata) Sherkin Island Marine Station, Sherkin Island, Co; Cork, Ireland: (1995).

[11] B. Karlson, C. Cusack, E. Bresnan, Microscopic and molecular methods for quantitative phytoplankton analysis, (IOC Manuals and Guides, no. 55.) Paris, UNESCO (2010) (IOC/2010/MG/55) $110 p$ 
[12] F.H. Chang, I. Garthwaite, D.M Anderson, N. Towers, R. Stewart, L. MacKenzie, Immunofluorescent detection of a PSP-producing dinoflagellate, Alexandrium minutum, from Bay of Plenty, New Zealand, N. Z. J. Mar. Freshw. Res. 33 (1999) 533-543.

[13] F. Gas, L. Pinto, B. Baus, L. Gaufres, M.P. Crassous, C. Compère, E. Quéméneur, Monoclonal antibody against the surface of Alexandrium minutum used in a whole-cell ELISA, Harmful Algae, 8 (2009) 538-545.

[14] M. Carrera, E. Garet, A. Barreiro, E. Garces, D. Perez, C. Guisande, A. GonzalezFernandez, Generation of monoclonal antibodies for the specific immunodetection of the toxic dinoflagellate Alexandrium minutum Halim from Spanish waters, Harmful algae 9 (2010) 272-280.

[15] N. Touzet, R. Raine, Discrimination of Alexandrium andersoni and A. minutum (Dinophyceae) using LSU rRNA-targeted oligonucleotide probes and fluorescent whole-cell hybridization, Phycologia, 46 (2007) 168-177.

[16] X.H Tang, R.C. Yu, M.J. Zhou, Z.G. Yu, Application of rRNA probes and fluorescence in situ hybridization for rapid detection of the toxic dinoflagellate Alexandrium minutum, Chin. J. Oceanol. Limnol. 30 (2012) 256-263.

[17] N. Touzet, E. Keady, R. Raine, M. Maher, Evaluation of taxa-specific real-time PCR, whole-cell FISH and morphotaxonomy analyses for the detection and quantification of the toxic microalgae Alexandrium minutum (Dinophyceae), Global Clade ribotype, FEMS microbiol. ecol. 67 (2009) 329-341.

[18] L. Galluzzi, A. Penna, E. Bertozzini, M. Vila, E. Garcés, M. Magnani, Development of Real time PCR assay for rapid detection and quantification of $A$. minutum (Dinoflagellate), Appl. Environ. Microbiol. 70 (2004) 1199-1206.

[19] F.Y. Zhang, Y.H. Shi, K.J. Jiang, Z.L. Xu, L.B. Ma, Sensitive and rapid detection of two toxic microalgae Alexandrium by loop-mediated isothermal amplification, Acta Oceanol. Sin. 31 (2012) 139-146.

[20] J.S. Ki, M.S. Han, A low-density oligonucleotide array study for parallel detection of harmful algal species using hybridization of consensus PCR products of LSU rDNA D2 domain. Biosens. Bioelectron., 21 (2006) 1812-1821.

[21] C. Gescher, K. Metfies, L.K. Medlin, The ALEX CHIP - Development of a DNA chip for identification and monitoring of Alexandrium, Harmful Algae 7 (2008) 485-494.

[22] L. Galluzzi, A. Cegna, S. Casabianca, A. Penna, N. Saunders, M. Magnani, Development of an oligonucleotide microarray for the detection and monitoring of marine dinoflagellates, J. Microbiol. Methods 84 (2011) 234-242.

[23] G.R. McCoy, N. Touzet, G.T. Fleming, R. Raine An evaluation of the applicability of microarrays for monitoring toxic algae in Irish coastal waters, Environ. Sci. Pollut. Res. 20 (2013) 6751-6764. 
[24] C. Noyer, A. Abot, L. Trouilh, V. Leberre-Anton, C. Dreanno, Phytochip: Development of a DNA-microarray for rapid and accurate identification of Pseudo-nitzschia spp and other harmful algal species, J. Microbiol. Methods, 112 (2015) 55-66.

[25] M. Lazerges, H., Perrot, E. Antoine, A. Defontaine, C. Compere, Oligonucleotide quartz crystal microbalance sensor for the microalgae Alexandrium minutum (Dinophyceae). Biosens. Bioelectron. 21 (2006) 1355-1358.

[26] J. Ryan, D. Greenfield, R. Marin, C. Preston, B. Roman, S. Jensen, D. Pargett, J. Birch, C. Mikulski, G. Doucette, C. Scholin, Harmful phytoplankton ecology studies using an autonomous molecular analytical and ocean observing network. Limnol. Oceanogr. 56 (2011) 1255-1272.

[27] S. Diercks-Horn, K. Metfies, S. Jackel, L.K. Medlin, The ALGADEC device: A semiautomated rRNA biosensor for the detection of toxic algae. Harmful algae, 10 (2011) 395401.

[28] C. Sousa, C. Compere, C. Dreanno, M.P. Crassous, F. Gas, B. Baus, H. Perrot, Direct and fast detection of Alexandrium minutum algae by using high frequency microbalance, $\mathrm{J}$ Microbiol Methods, 104 (2014) 49-54.

[29] R. Wong, H. Tse, Lateral flow immunoassay, Humana Press, Springer, New York, 2010. [30] Z.J. Tsao, Y.C. Liao, B.H. Liu, C.C Su, F.Y. Yu, Development of a monoclonal antibody against domoic acid and its application in enzyme-linked immunosorbent assay and colloidal gold immunostrip. J. Agric. Food Chem. 55 (2007) 4921-4927.

[31] M.V Laycock, M.A. Donovan, D. Easy, Sensitivity of lateral flow tests to mixtures of saxitoxins and applications to shellfish and phytoplankton monitoring, Toxicon 55 (2010) 597605.

[32] B.T.L. Eberhart, L.K. Moore, N. Harrington, N.G. Adams, J. Borchert, V.L. Trainer, Screening tests for the rapid detection of diarrhetic shellfish toxins in Washington state, Marine drugs. 11 (2013) 3718-3734.

[33] W. Jawaid, K. Campbell, K. Melville, S.J. Holmes, J. Rice, C.T. Elliott, Development and validation of a novel lateral flow immunoassay (LFIA) for the rapid screening of paralytic shellfish toxins (PSTs) from shellfish extracts, Anal. Chem. 87 (2015) 5324-5332.

[34] W. Jawaid, J. Meneely, K. Campbell, M. Hooper, K. Melville, S. Holmes, J. Rice, C. Elliott, Development and validation of the first high performance-lateral flow immunoassay (HP-LFIA) for the rapid screening of domoic acid from shellfish extracts, Talanta 116 (2013) 663-669.

[35] B.H. Liu, C.T. Hung, C.C. Lu, H.N. Chou, F.Y. Yu, Production of monoclonal antibody for okadaic acid and its utilization in an ultrasensitive enzyme-linked immunosorbent assay and one-step immunochromatographic strip, J. Agric. Food Chem. 62 (2014) 1254-1260. 
[36] L. Anfossi, C. Baggiani, C. Giovannoli, G. D’arco, G. Giraudi, Lateral -flow immunoassay for mycotoxins and phycotoxins : a review, Anal. Bioanal. Chem. 405 (2013) 467-480.

[37] L. Shi, F. Wu, Y. M. Wen, F. Zhao, J.J. Xiang, L. Ma, A novel method to detect Listeria monocytogenes via superparamagnetic lateral flow immunoassay, Anal. Chem. 407 (2015) 529-535.

[38] F. Gas, B. Baus, L. Pinto, C. Compère, V. Tanchou, E. Quéméneur, 2010. One step immunochromatographic assay for the rapid detection of Alexandrium minutum, Biosens. Bioelectron., 25 (2010) 1235-1239.

[39] I.Y. Goryacheva, P. Lenain, S. De Saeger, Nanosized labels for rapid immunotests, Trac-Trends Anal. Chem. 46 (2013) 30-43.

[40] R. T. LaBorde and B. O'Farrell. Paramagnetic-particle detection in lateral-flow assays, IVD Technology (2002) 36-41.

[41] L. Lenglet, P. Nikitin, C. Pequignot, Magnetic immunoassays: a new paradigm in POCT IVD Technology July/August, 43 (2008)

[42] R.B. Peck, J. Schweizer, B.H. Weigl, C. Somoza, J. Silver, J.W. Sellors, A magnetic immunochromatographic strip test for detection of human papillomavirus $16 \mathrm{E} 6$, Clin. Chem. 52 (2006) 2170-2172.

[43] Q.F. Xu, H. Xu, H.C. Gu, J.B. Li, Y. Wang, M. Wei, Development of lateral flow immunoassay system based on superparamagnetic nanobeads as labels for rapid quantitative detection of cardiac troponin I, Mater. Sci. Eng. C, 29 (2009) 702-707.

[44] S. Puertas, M. Moros, R. Fernández-Pacheco, M. R. Ibarra, V. Grazú, J. M. de la Fuente, Designing novel nano-immunoassays: antibody orientation versus sensitivity, J. Phys. D: Appl. Phys., 43 (2010), 474012, 8pp.

[45] S. Handali, M. Klarman, A.N. Gaspard, X.F. Dong, R. Laborde, J. Noh, Y.M. Lee, S. Rodriguez, A.E. Gonzalez, H.H. Garcia, R.H. Gilman, V.C. Tsang, P.P. Wilkins, Development and evaluation of a magnetic immunochromatographic test to detect Taenia solium, which causes taeniasis and neurocysticercosis in human, Clin Vaccine Immunol., 17 (2010), 631-7.

[46] Q. Yu, H. Yang, Y. Feng, X. Yang, Y. Zhu, Magnetic affinity enzyme-linked immunoassay based on recombinant $26 \mathrm{kDa}$ glutathione-S-transferase for serological diagnosis of schistosomiasis japonica, Acta Trop., 124 (2012) 199-202.

[47] C. Zheng, X.C. Wang, Y. Lu, Y. Liu, Rapid detection of fish major allergen parvalbumin using superparamagnetic nanoparticle-based lateral flow immunoassay, Food control, 26 (2012) 446-452.

[48] D.B. Wang, B. Tian, Z.P. Zhang, J.Y. Deng, Z.Q. Cui, R.F. Yang, X.Y. Wang, H.P. Wei, X.E. Zhang, Rapid detection of Bacillus anthracis spores using a super-paramagnetic lateralflow immunological detection system, Biosens. Bioelectron. 42 (2013) 661-667. 
[49] Y.M. Kim, S.W. Oh, S.Y. Jeong, D.J. Pyo, E.Y. Choi, Development of an ultra rapid onestep fluorescence immunochromatographic assay system for the quantification of microcystins. Environ. Sci. Technol. 37 (2003), 1899.

[50] C.X. Chen, J. Wu, A fast and sensitive quantitative lateral flow immunoassay for Cry1Ab based on a novel signal amplification conjugate, Sensors 12 (2012) 11684-11696.

[51] F. Zhang, M.Q. Zou, Y. Chen, J.F. Li, Y.F. Wang, X.H. Qi, Q. Xue, Lanthanide-labeled immunochromatographic strips for the rapid detection of Pantoea stewartii subsp stewartii. Biosens. Bioelectron. 51 (2014) 29-35

[52] A. Sakurai, K. Takayama, N. Nomura, N. Kajiwara, M.S. Okamatsu, N. Yamamoto, T. Tamura, J. Yamada, M. Hashimoto, Y. Sakoda, Y. Suda, Y. Kobayashi, H. Kida, F. Shibasaki, Fluorescent immunochromatography for rapid and sensitive typing of seasonal influenza viruses, PLOS One 10 (2015) e0116715.

[53] Z.H. Li, Y. Wang, J. Wang, Z.W. Tang, J.G. Pounds, Y.H. Lin, Rapid and sensitive detection of protein biomarker using a portable fluorescence biosensor based on quantum dots and a lateral flow test strip, Anal. Chem. 82 (2010) 7008-7014.

[54] A.N. Berlina, N.A. Taranova, A.V. Zherdev, Y.Y. Vengerov, B.B. Dzantiev, Quantum dotbased lateral flow immunoassay for detection of chloramphenicol in milk, Anal. Bioanal. Chem. 405 (2013) 4997-5000.

[55] X. Li, W.B. Li, Q.H. Yang, X.Q. Gong, W.S. Guo, C.H. Dong, J.Q. Liu, L.X. Xuan, J. Chang, Rapid and quantitative detection of prostate specific antigen with a quantum dot nanobeads-based immunochromatography test strip, ACS Appl. Mater. Interfaces 6 (2014) 6406-6414.

[56] J. Shen, Y.F. Zhou, F. Fu, H.Y. Xu, J.F. Lv, Y.H. Xiong, A. Wang, Immunochromatographic assay for quantitative and sensitive detection of hepatitis $B$ virus surface antigen using highly luminescent quantum dot-beads, Talanta 142 (2015) 145-149.

[57] A. Merkoçi, Nanoparticles-based strategies for DNA, protein and cells sensors, Biosens. Bioelectron. 26 (2010) 1164-1177.

[58] R.A. Andersen, Algal Culturing Techniques, Elsevier (2005), p. 565.

[59] L. Lenglet, Multiparametric magnetic immunoassays utilizing non-linear signatures of magnetic labels, J. Magn. Magn. Mater. 321 (2009) 1639-1643.

[60] Magnisense, Analysis of biological and/or chemical mixtures using magnetic particles RU2001000100.

[61] P.I. Nikitin, P.M. Vetoshko, T.I. Ksenevich, New type of biosensor based on magnetic nanoparticle detection, J. Magn. Magn. Mater. 311 (2007) issue 1.

[62] P.I. Nikitin, P.M. Vetoshko, T.I. Ksenevich, Magnetic immunoassays, Sens. Lett. 5 (2007) 296-299. 
[63] B. Ngom, Y.C. Guo, X.L. Wang, D.R. Bi, Development and application of lateral flow test strip technology for detection of infectious agents and chemical contaminants: a review, Anal. Bioanal. Chem. 397 (2010) 1113-1135.

[64] P. Sithigorngul, S. Rukpratanporn, N. Pecharaburanin, P. Suksawat, S. Longyant, P. Chaivisuthangkura, W. Sithigorngul, A simple and rapid immunochromatographic test strip for detection of pathogenic isolates of Vibrio harveyi, J Microbiol Methods, 71 (2007) 256264.

[65] S. Wiriyachaiporn, P.H. Howarth, K.D. Bruce, L.A. Dailey, Evaluation of a rapid lateral flow immunoassay for Staphylococcus aureus detection in respiratory samples, Diagn. Microbiol. Infect. Dis. 75 (2013) 28-36.

[66] N. Wiriyachaiporn, W. Maneeprakorn, C. Apiwat, T. Dharakul, Dual-layered and doubletargeted nanogold based lateral flow immunoassay for influenza virus, Microchim. Acta 182 (2015) 85-93.

[67] L.K. Eckford-Soper, N. Daugbjerg, Examination of six commonly used laboratory fixatives in $\mathrm{HAB}$ monitoring programs for their use in quantitative PCR based on Taqman probe technology, Harmful algae 42 (2015) 52-59.

[68] R.K. Naik, R.R. Chitari, A.C. Anil, Karlodinium veneficum in India: effect of fixatives on morphology and allelopathy in relation to Skeletonema costatum, Curr. Sci. 8 (2010) 11121116.

[69] A. Chapelle, C. Labry, M. Sourisseau, C. Lebreton, A. Youenou, M.P. Crassous. Alexandrium minutum growth controlled by phosphorus : an applied model J. Mar. Syst. 83 (2010) 181-191.

[70] A. Chapelle, M. Le Gac, C. Labry, R. Siano, J. Quere, F. Caradec, C. Le Bec, E. Nezan, A. Doner, J. Gouriou, The Bay of Brest (France), a new risky site for toxic Alexandrium minutum blooms and PSP shellfish contamination, Harmful Algae News (2015) 4-5.

[71] EN-15204 (2006) - Water quality- Guidance standard for the routine analysis of phytoplankton abundance and composition using inverted microscope (Utermöhl technique).

\section{Figures caption:}

Figure 1. Diagram of the magnetic lateral-flow immunological detection system for Alexandrium minutum cells detection.

\section{Figure 2. Typical responses of LFIA}

Magnetic scan of the immunostrips for Alexandrium minutum performed with superparamagnetic beads. Several algae concentrations were scanned: $10^{7}$ cells.L- ${ }^{1}, 7.10^{6}$ cells.L- ${ }^{1} 2 \times 10^{6}$ cells $/ \mathrm{L}^{-1}, 2.10^{5}$ cells. $\mathrm{L}^{-1}, 2.10^{4}$ cells.L-1, and seawater for the control $\left(0\right.$ cell. $\mathrm{L}^{-}$ 
$\left.{ }^{1}\right)$. The scan shows the three parts of the immunostrips: Part A, the sample pad zone; Part

$B$, the nitrocellulose zone including the test line and Part $C$, the absorbent pad.

Figure 3. Specific detection of Alexandrium minutum cells

Seawater and different dinoflagellate samples were tested.

Figure 4. Calibration curve obtained with different cell concentrations of $\boldsymbol{A}$. minutum

The $\mathrm{X}$ axe data, i.e the cell concentration are expressed on a logarithm scale in the inserted graphic.

Figure 5. Comparison of LFIA and microscope methods for whole cells enumeration in sea water samples.

The solid line indicates the results from a linear regression of our data and the dashed line represents the theoretical 1:1 relationship. Points below the 1:1 dashed line represent cases where LFIA detects more cells than optical microscopy counting (i.e overestimation) whereas points above the 1:1 dashed line are instances where LFIA underestimates cell concentrations

\section{Highlights}

_ A fast and highly specific magnetic LFIA to detect and quantify a toxic microalgae

_ The magnetic LFIA is able to quantify living and frozen whole cells.

- The efficiency of LFIA was compared to standard method during bloom monitoring

_ This user-friendly biosensor can be used for rapid on site testing.

_ This quantitative LFIA will improve the performance of the monitoring program. 


\section{Tables}

Table 1. Effect of Lugol's iodine solution concentration on LFIA performance. Magnetic signals were measured after $30 \mathrm{~min}$ at the Test line. Unfixed $A$. minutum culture, i.e fresh living cells constituted the control.

\begin{tabular}{|c|c|c|c|c|}
\hline \multirow[b]{2}{*}{ Time (day) } & \multirow[b]{2}{*}{ Control } & \multirow[b]{2}{*}{$0.5 \%$} & \multicolumn{2}{|c|}{ Lugol's iodine solution } \\
\hline & & & $1 \%$ & $2 \%$ \\
\hline 1 & $407 \pm 16^{a}$ & $405 \pm 17^{a}$ & $245 \pm 10^{b}$ & $252 \pm 11^{b}$ \\
\hline 7 & - & $417 \pm 13^{a}$ & $268 \pm 11^{b}$ & $257 \pm 18^{b}$ \\
\hline 14 & - & $381 \pm 7^{b}$ & $249 \pm 13^{c}$ & $239 \pm 12^{c}$ \\
\hline \multicolumn{5}{|c|}{$\begin{array}{l}\text { Values between columns followed by different superscripts are significantly } \\
(\mathrm{P}<0.05)\end{array}$} \\
\hline & \multicolumn{2}{|c|}{ PBS } & \multicolumn{2}{|c|}{ Seawater } \\
\hline $\begin{array}{l}\text { Concentration } \\
\text { (cells/L) }\end{array}$ & Living cells & Frozen cells & Living cells & Frozen cells \\
\hline $1.10^{5}$ & $338 \pm 10$ & $334 \pm 7$ & $326 \pm 8$ & $335 \pm 8$ \\
\hline $1.10^{6}$ & $373 \pm 12$ & $371 \pm 11$ & $375 \pm 11$ & $357 \pm 10$ \\
\hline $1.10^{7}$ & $410 \pm 8$ & $413 \pm 10$ & $404 \pm 8$ & $391 \pm 9$ \\
\hline
\end{tabular}


Table 3. Determination of $\boldsymbol{A}$. minutum concentrations in seawater samples.

Seawater samples were spiked with known quantity of cells from phytoplankton cultures.

\begin{tabular}{|c|c|c|}
\hline $\begin{array}{c}\text { Cell concentration } \\
\text { (optical microscopy, OM) }\end{array}$ & $\begin{array}{l}\text { Cell concentration } \\
\text { (LFIA) }\end{array}$ & OM/FLIA \\
\hline $2,45 \cdot 10^{8}$ & $3,44 \pm 1,24.10^{8}$ & 0,71 \\
\hline $1,25.10^{8}$ & $1,33 \pm 0,53 \cdot 10^{8}$ & 0,94 \\
\hline $5,50.10^{7}$ & $5,13 \pm 3,28.10^{7}$ & 1,07 \\
\hline $5,00 \cdot 10^{7}$ & $4,34 \pm 1,56.10^{7}$ & 1,15 \\
\hline $2,50.10^{7}$ & $2,26 \pm 1,33.10^{7}$ & 1,10 \\
\hline $6,00.10^{6}$ & $5,21 \pm 0,67.10^{6}$ & 1,15 \\
\hline $5,00 \cdot 10^{6}$ & $4,75 \pm 1,31 \cdot 10^{6}$ & 1,06 \\
\hline $4,00.10^{6}$ & $3.74 \pm 0,40.10^{6}$ & 1,10 \\
\hline $2,00.10^{6}$ & $2,15 \pm 0,71 \cdot 10^{6}$ & 0,93 \\
\hline $1,25.10^{6}$ & $1,09 \pm 0,45 \cdot 10^{6}$ & 1,15 \\
\hline $6,00 \cdot 10^{5}$ & $6,27 \pm 1,46 \cdot 10^{5}$ & 0,96 \\
\hline $5,00.10^{5}$ & $6,22 \pm 1,71 \cdot 10^{5}$ & 0,80 \\
\hline $2,00.10^{5}$ & $2,08 \pm 0.60 .10^{5}$ & 0,96 \\
\hline $6,00.10^{4}$ & $1,16 \pm 0.40 .10^{5}$ & 0,52 \\
\hline $5,00 \cdot 10^{4}$ & $8,48 \pm 2,06 \cdot 10^{4}$ & 0,59 \\
\hline
\end{tabular}


Figure1

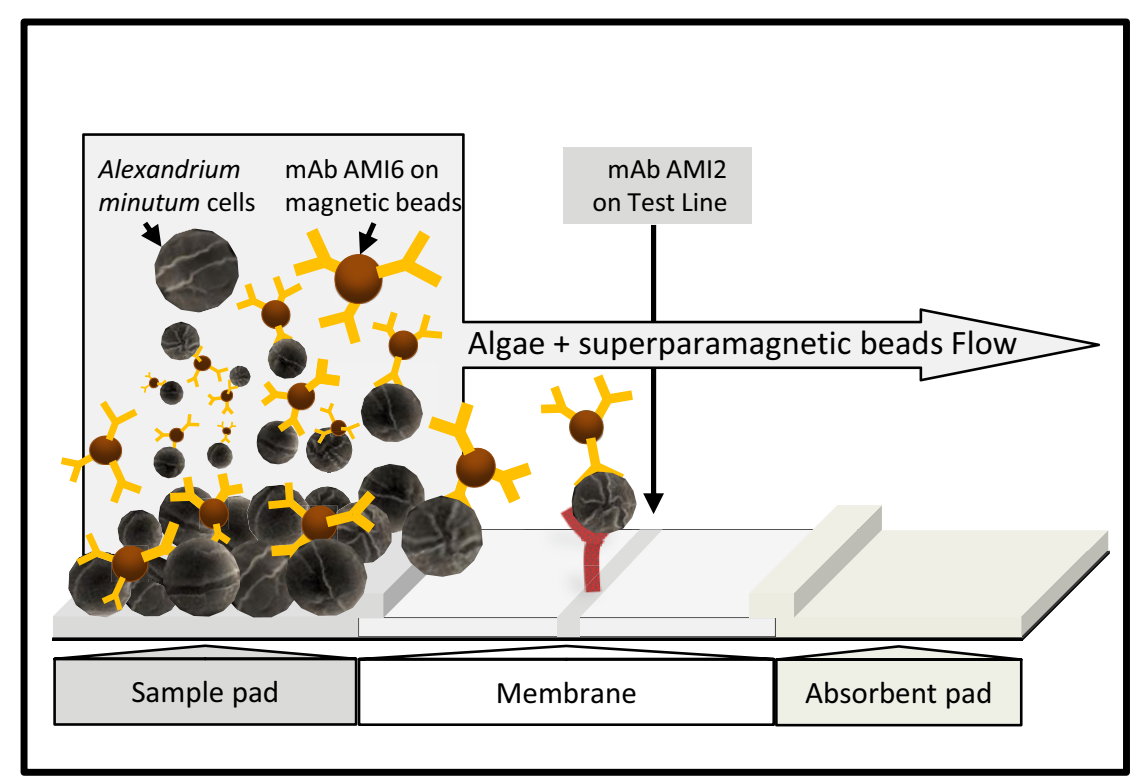




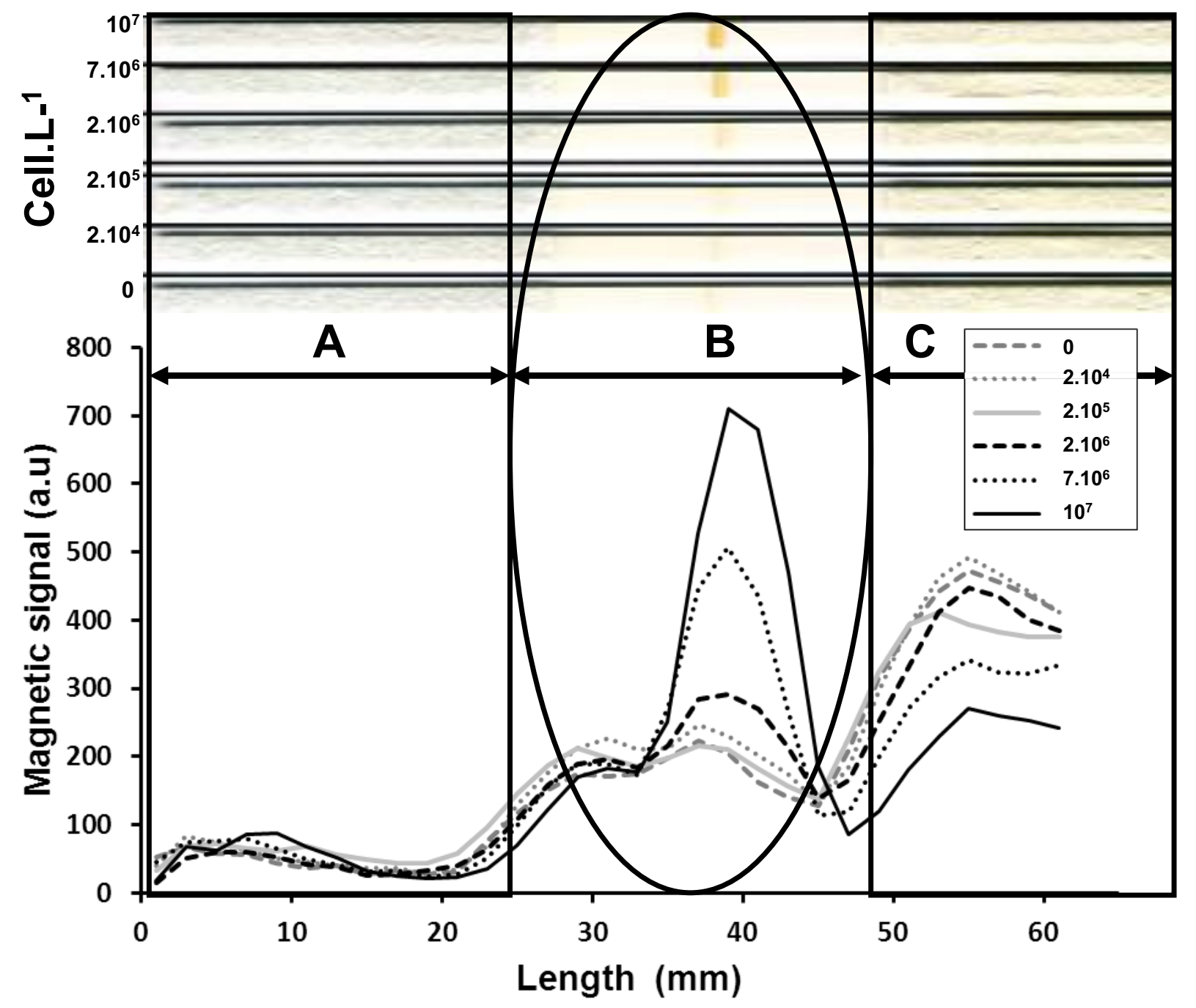


Figure3

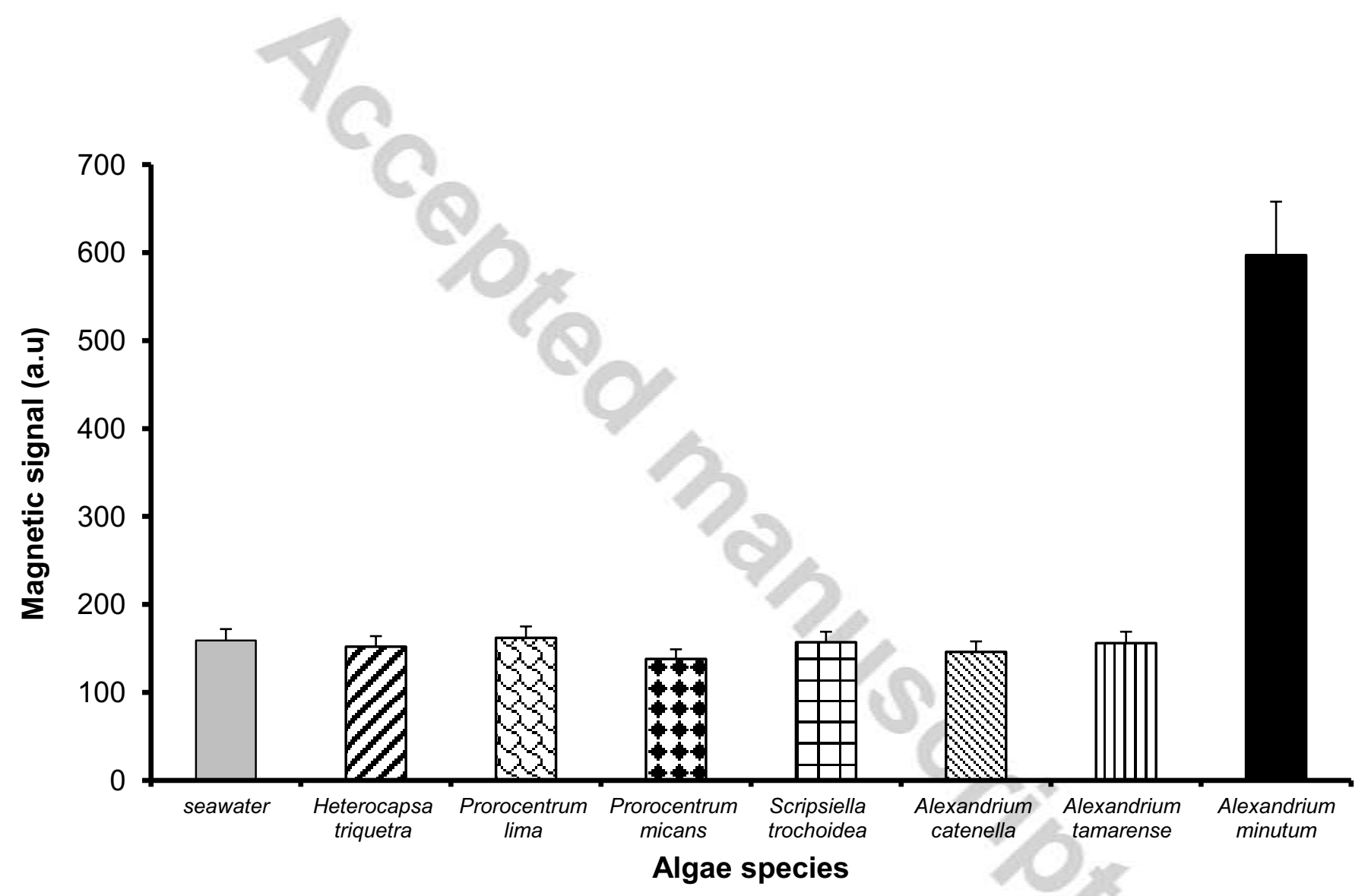


Figure4

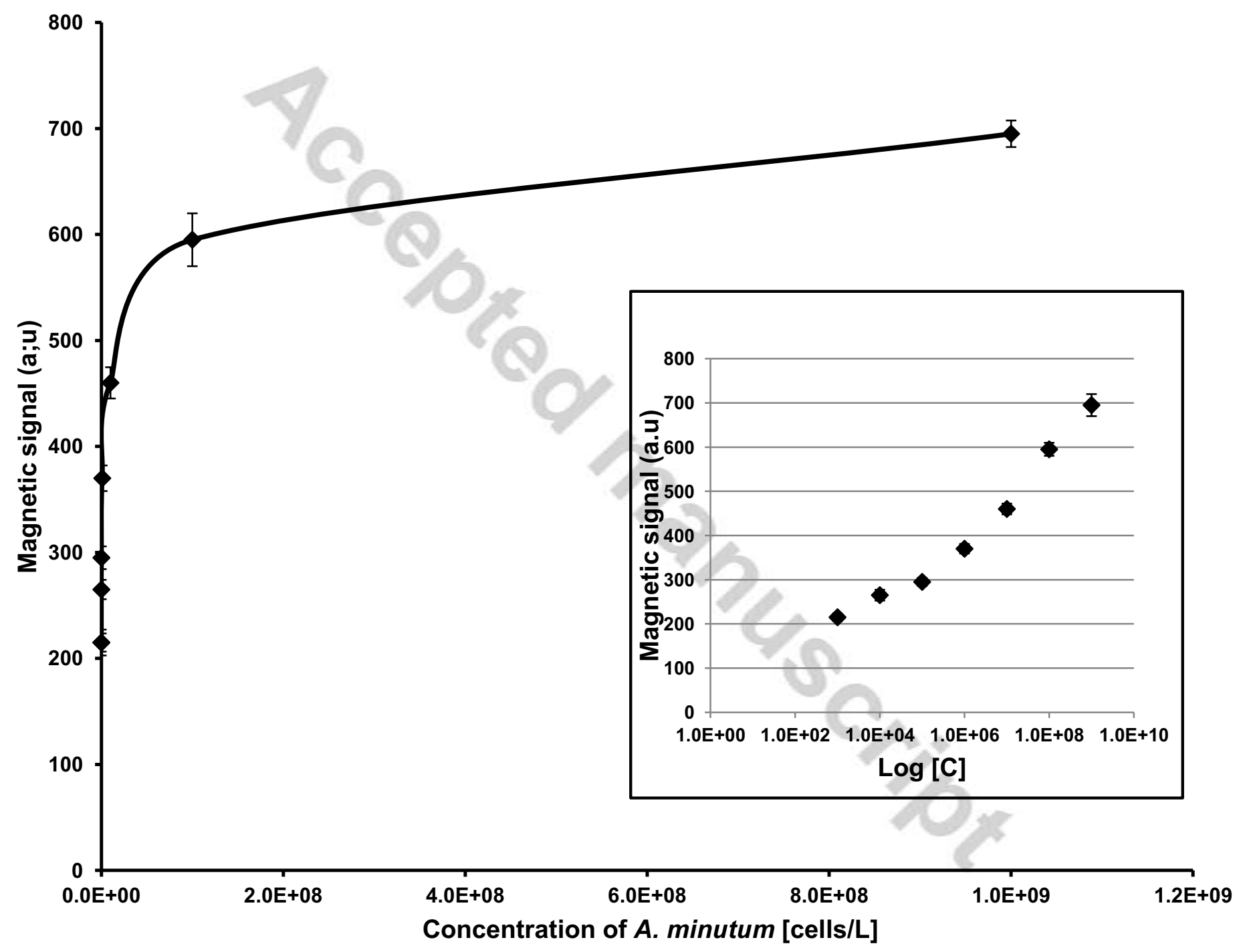




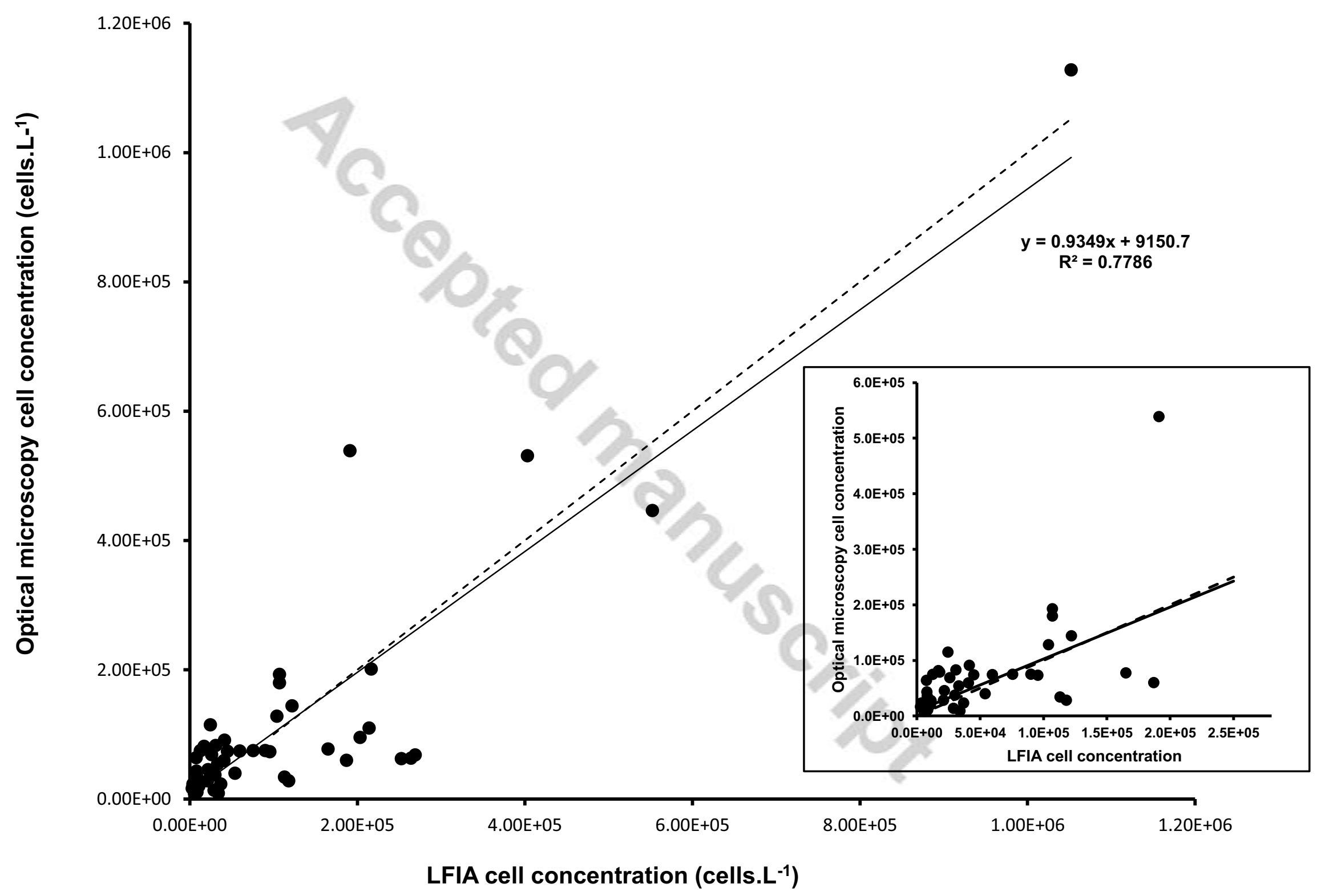




\section{Alexandrium minutum identification and quantification}

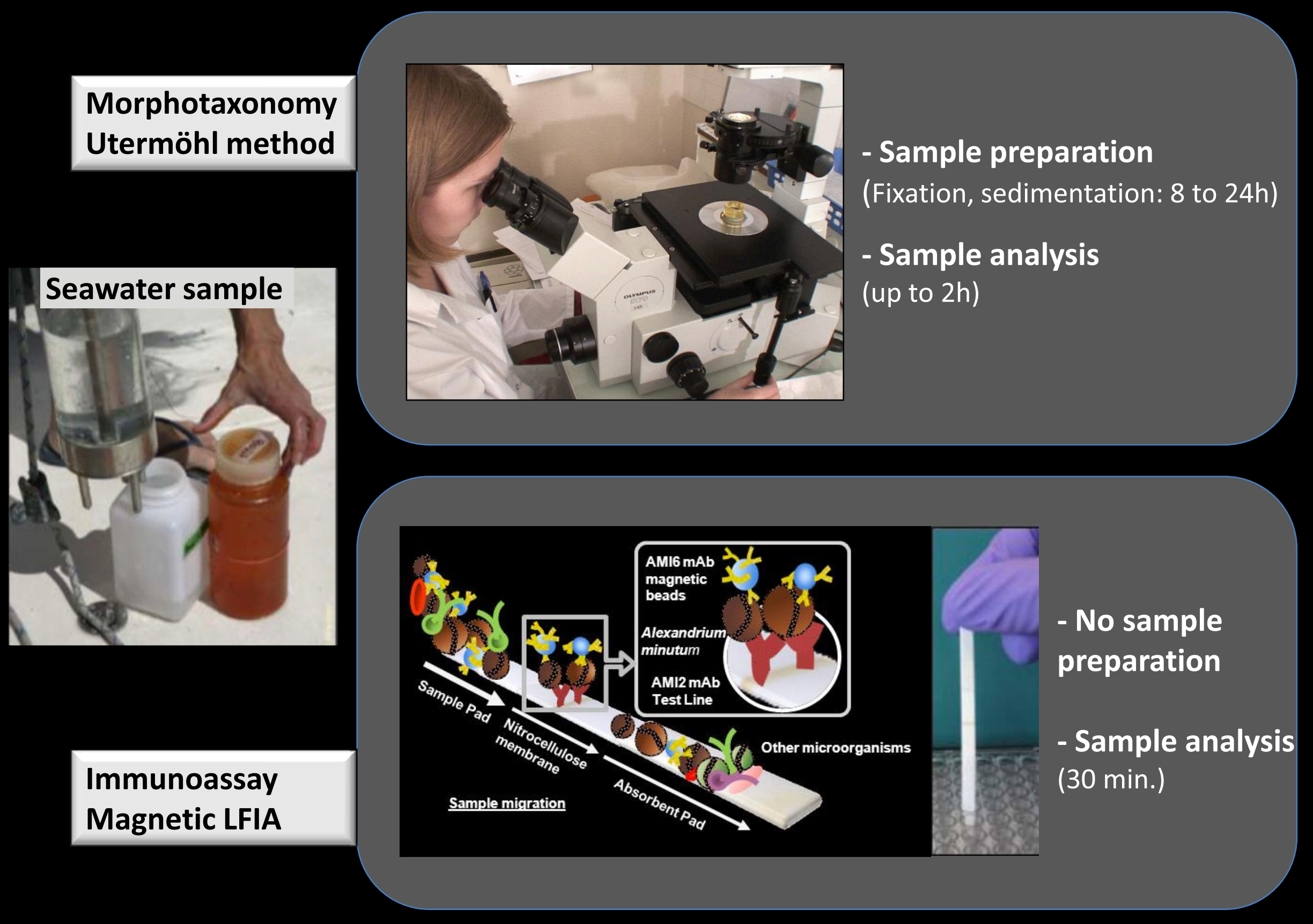

